\title{
Socio-demographic aspects of chronic urticaria and the structure of hospitalization in patients of the Department of Dermatology, Poznan University of Medical Sciences
}

\author{
Zagadnienia społeczno-demograficzne dotyczące pokrzywki przewlekłej \\ a struktura hospitalizacji pacjentów w Klinice Dermatologii \\ Uniwersytetu Medycznego w Poznaniu
}

Anna Błaszczyk', Dorota Jenerowicz', Filip Raciborski², Anna Sadowska-Przytocka', Zygmunt Adamski², Magdalena Czarnecka-Operacz'

'Department of Allergic and Occupational Skin Diseases, Poznan University of Medical Sciences, Poznan, Poland 2Department of Prevention of Environmental Hazards and Allergology, Medical University of Warsaw, Warsaw, Poland ${ }^{3}$ Department of Dermatology, Poznan University of Medical Sciences, Poznan, Poland

'Zakład Alergicznych i Zawodowych Chorób Skóry, Uniwersytet Medyczny im. Karola Marcinkowskiego, Poznań, Polska 2Zakład Profilaktyki Zagrożeń Środowiskowych i Alergologii, Warszawski Uniwersytet Medyczny, Warszawa, Polska ${ }^{3}$ Klinika Dermatologii, Uniwersytet Medyczny im. Karola Marcinkowskiego, Poznań, Polska

\section{CORRESPONDING AUTHOR/} AUTOR DO KORESPONDENCJI: dr Anna Błaszczyk Zakład Alergicznych i Zawodowych Chorób Skóry Uniwersytet Medyczny im. Karola Marcinkowskiego Poznań, Polska tel.: +48507860311 e-mail: a.noowak@gmail.com

\begin{abstract}
Introduction: Urticaria is a disease with a complex pathomechanism that is characterized by the occurrence of wheals, edema or both.

Objective: To analyze the demographic aspects in a chronic urticaria patient and the structure of his hospitalization.

Material and methods: The study was divided into two parts - the retrospective part $(\mathrm{R})$ and the prospective part $(\mathrm{P})$. The retrospective part included 441 chronic urticaria patients at the age of 15 or older, hospitalized during the recent 10 years. The study analyzed history of the disease and database was established. For the prospective analysis 78 patients have been selected out of 441 subjects qualified for retrospective analysis, suffering from chronic aspirin-exacerbated disease, spontaneous, autoimmune and induced urticaria.

Results: Chronic urticaria mainly affected women (75.7\% R; 79.5\% P). The vast majority of patients lived in the city $(75.7 \% \mathrm{R} ; 64.1 \% \mathrm{P})$ and most of them were professionally active $(50.1 \% \mathrm{R} ; 56.4 \% \mathrm{P})$. In the prospective part it was found that over half of the group still had chronic urticaria (55.1\%). Most patients were admitted to the Department in March $(11.1 \%)$ or February $(10.4 \%)$. The referring specialist was most commonly a dermatologist $(95 \%)$. Least commonly the patients were referred by general practitioners $(2 \%)$.

Conclusions: The results obtained in this analysis suggest a correlation between the severity of symptoms and increased diversity of the diet, as well as a lower number of admissions during vacation time.
\end{abstract}

Key words: chronic urticaria, epidemiology, demography. 


\section{STRESZCZENIE}

Wprowadzenie: Pokrzywka jest dermatozą o złożonym patomechanizmie, która charakteryzuje się występowaniem zmian skórnych w postaci bąbli, obrzęku lub obu tych objawów jednocześnie.

Cel pracy: Analiza uwarunkowań demograficznych u chorych na pokrzywkę przewlekłą oraz struktury ich hospitalizacji.

Materiał i metody: Badanie zostało podzielone na dwie części: retrospektywną (R) i prospektywną (P). Część retrospektywna obejmowała łącznie 441 pacjentów chorujących na pokrzywkę przewlekłą, w wieku co najmniej 15 lat, hospitalizowanych w czasie 10 lat. W ramach badania przeanalizowano historie choroby pacjentów i sworzono bazę danych. Do analizy prospektywnej wybrano 78 pacjentów spośród 441 osób zakwalifikowanych do analizy retrospektywnej. Grupa obejmowała pacjentów z przewlekłą pokrzywką aspirynową, samoistną, autoimmunologiczną i indukowaną.

Wyniki: Pokrzywka przewlekła występowała głównie u kobiet (75,7\% R; 79,5\% P). Większość analizowanych pacjentów mieszkała w mieście (75,7\% R; 64,1\% P). Większość osób była aktywna zawodowo (50,1\% R; 56,4\% P). W części P badania stwierdzono, że u ponad połowy osób $\mathrm{z}$ analizowanej grupy nadal występuje pokrzywka przewlekła $(55,1 \%)$. Większość przyjęć do Kliniki stwierdzono w marcu $(11,1 \%)$ i lutym $(10,4 \%)$. Specjalistą najczęściej kierującym chorych do Kliniki był dermatolog (95\%). Najrzadziej pacjenci byli kierowani przez lekarzy rodzinnych (2\%).

Wnioski: Wyniki uzyskane w ramach analizy mogą wskazywać na związek nasilenia objawów ze zróżnicowaniem diety. Zauważalna jest także mniejsza liczba przyjęć w okresach wakacyjnych i świątecznych.

Słowa kluczowe: pokrzywka przewlekła, epidemiologia, demografia.

\section{INTRODUCTION}

Urticaria is a disease with a complex pathomechanism that is characterized by the occurrence of wheals, edema or both. The pathomechanism is associated with mast cell degranulation. The result of the activity of various mediators released from mast cells or basophils is the expansion of small vessels, increased their permeability and plasma exudation into intercellular spaces. The main mediator is histamine. Skin changes are accompanied by pruritus and/or sometimes burning sensation. Different types of urticaria have a very wide range of clinical manifestations and in one patient more than one of its types may co-exist.

In most cases it is very difficult to determine the cause of the skin lesions, although some factors that underlie the pathogenetic mechanisms can be distinguished. Therefore urticaria is classified in terms of its duration and causes and chronic urticaria (CU), lasting more than 6 weeks, as chronic spontaneous urticaria (CSU) and chronic induced urticaria (CIU) caused by

\section{WPROWADZENIE}

Pokrzywka jest dermatozą o złożonym patomechanizmie, która charakteryzuje się występowaniem zmian skórnych w postaci bąbli, obrzęku lub obu tych objawów jednocześnie. Patomechanizm schorzenia wiąże się z degranulacją komórek tucznych. Działanie różnych mediatorów uwalnianych $\mathrm{z}$ mastocytów i granulocytów zasadochłonnych powoduje rozszerzenie drobnych naczyń krwionośnych, ich zwiększoną przepuszczalność oraz wysięk osocza do przestrzeni międzykomórkowych. Głównym mediatorem jest histamina. Zmianom skórnym towarzyszy świąd i/lub sporadycznie uczucie pieczenia. Różne odmiany pokrzywki mają bardzo szeroki zakres obrazów klinicznych, a u jednego pacjenta może współistnieć więcej niż jeden podtyp tego schorzenia.

W większości przypadków bardzo trudno jest ustalić przyczynę zmian skórnych, choć można wyróżnić pewne czynniki leżące u podstawy mechanizmów patogenetycznych. Pokrzywkę można sklasyfikować pod względem czasu 
external physical factors (e.g. pressure, cold, heat, active or passive temperature increase or vibration) [1, 2].

Data regarding epidemiology of urticaria in the Polish population are minimal and insufficient. The incidence of urticaria has been observed in $5 \%$ of children aged $6-7$ years, $5 \%$ of children aged $13-14$ years and $8 \%$ of adults.

\section{OBJECTIVE}

The aims of the study were to analyze the demographic aspects in a CU patient and the structure of his hospitalization.

\section{MATERIAL AND METHODS}

The study was divided into two parts - the retrospective one $(\mathrm{R})$ and the prospective one $(\mathrm{P})$. The retrospective analysis included $441 \mathrm{CU}$ patients at the age of 15 or older hospitalized in the Department of Dermatology, Poznan University of Medical Sciences during 10 years. The study analyzed history of the disease of all patients and then anonymized information has been placed in a specially designed form. For the prospective analysis 78 patients have been chosen out of 441 subjects previously qualified for retrospective analysis, suffering from chronic aspirin-exacerbated disease, spontaneous, autoimmune and induced urticaria. Ethical committee approval Poznan University of Medical Sciences: 569/15.

\section{Statistical analysis}

Statistical analysis was carried out using the IBM SPSS program (ver. 23).

\section{RESULTS}

Chronic urticaria mainly affected women $(75.7 \%$ for R part and $79.5 \%$ for P part). Most patients were at the age of $15-34$ for $R$ and $34-54$ for P. The average age of the occurrence of the first episode was for R $37 \pm 14.1$ years, and for $P 36.3 \pm 16.5$ years (table 1 ).

The vast majority of respondents lived in a city $(75.7 \%$ for $\mathrm{R}$ and $64.1 \%$ for $\mathrm{P}$ ), and most of them had were working ( $50.1 \%$ for $\mathrm{R}$ and $56.4 \%$ for $\mathrm{P}$ ) (tables 2 and 3 ).

In the prospective study it was found that over half of the group $(55.1 \%)$ still suffered from CU (subgroup I), while the remaining $44.9 \%$ no longer had symptoms of the disease (subgroup II).

Most frequently patients were admitted to the Department in March (11.1\%), February (10.4\%), June (10.2\%), October and November (9.3\%) (fig. 1). The specialist who was mostly referring patients to the Department was a dermatologist (95\%). The most seldom patients were referred by allergists (3\%) and general practitioners (2\%). The admission was mostly planned (97.7\%). trwania i przyczyny. Pokrzywka przewlekła (chronic urticaria - CU) utrzymuje się przez powyżej 6 tygodni i można ją dalej podzielić na pokrzywkę przewlekłą samoistną (chronic spontaneous urticaria - CSU) i pokrzywkę przewlekłą indukowaną (chronic induced urticaria - CIU) wywołaną zewnętrznymi czynnikami fizycznymi, do których należy m.in. ucisk, zimno, ciepło, aktywny lub pasywny wzrost temperatury lub drgania $[1,2]$.

Dane obrazujące epidemiologię pokrzywki w populacji polskiej są bardzo skąpe i niewystarczające. Częstość występowania pokrzywki określono na 5\% u dzieci w wieku 6-7 lat, 5\% u dzieci w wieku 13-14 lat oraz 8\% u osób dorosłych.

\section{CEL PRACY}

Celem pracy była analiza zagadnień demograficznych u chorych na CU oraz struktury ich hospitalizacji.

\section{MATERIA $Ł$ I METODY}

Badanie podzielono na dwie części: retrospektywną $(\mathrm{R})$ i prospektywną $(\mathrm{P})$. Analizą retrospektywną objęto łącznie 441 pacjentów z CU w wieku co najmniej 15 lat, hospitalizowanych w Klinice Dermatologii Uniwersytetu Medycznego w Poznaniu w czasie 10 lat. $W$ ramach badania przeanalizowano historie choroby wszystkich pacjentów, a pozyskane informacje (po ich anonimizacji) wprowadzono do specjalnie opracowanego formularza. Do analizy prospektywnej wybrano 78 pacjentów spośród 441 chorych zakwalifikowanych wcześniej do analizy retrospektywnej. Grupa obejmowała pacjentów z przewlekłą pokrzywką aspirynową, samoistną, autoimmunologiczną i indukowaną. Zgoda Komisji Bioetycznej Uniwersytetu Medycznego w Poznaniu: 569/15.

\section{Analiza statystyczna}

Analizę statystyczną przeprowadzono w programie IBM SPSS (w wersji 23).

\section{WYNIKI}

Pokrzywka przewlekła dotyczyła głównie kobiet (75,7\% w części R i 79,5\% w części P badania). Wiek większości pacjentów mieścił się w przedziale 15-34 lat (R) i 34-54 lat (P). Średni wiek, w którym wystąpił pierwszy epizod pokrzywki, wynosił $37 \pm 14,1$ roku (R) i 36,3 $\pm 16,5$ roku (P) (tab. 1).

Większość analizowanych pacjentów mieszkała w mieście $(75,7 \%$ R; 64,1\% P). Większość osób była aktywna zawodowo (50,1\% R; 56,4\% P) (tab. 2 i 3).

W badaniu prospektywnym wykazano, że CU nadal występuje $\mathrm{u}$ ponad połowy badanej grupy 
Table I. Mean age of onset of the first episode of chronic urticaria $(n=76)$

Tabela I. Średni wiek, w którym wystąpił pierwszy epizod pokrzywki przewlekłej $(n=76)$

\begin{tabular}{lcccc} 
Patients/Pacjenci & $\begin{array}{c}\text { Mean age of onset of the first episode [years]/Średni } \\
\text { wiek, w którym wystapił pierwszy epizod [lata] } \\
\mathbf{x} \pm \text { SD }\end{array}$ & $\begin{array}{c}\text { Median [years]// } \\
\text { Mediana [lata] }\end{array}$ & $\begin{array}{c}\text { Minimum [years]/ } \\
\text { Minimalny [lata] }\end{array}$ & $\begin{array}{c}\text { Maximum [years]/ } \\
\text { Maksymalny [lata] }\end{array}$ \\
\hline Total/tącznie & $37 \pm \mid 4.1$ & 35 & 15 & 67 \\
\hline Female/Kobiety & $37.5 \pm 14.9$ & 35 & 15 & 67 \\
\hline Male/Mężczyźni & $34.9 \pm 11$ & 34.5 & 22 & 55 \\
\hline
\end{tabular}

Table 2. Socio-demographic data of $\mathrm{R}$ patients $(n=44 \mathrm{I})$

Tabela 2. Charakterystyka socjodemograficzna pacjentów z grupy $R$ $(n=44 I)$

\begin{tabular}{lcc} 
Parameter/Parametr & $N$ & $\%$ \\
Sex/Płeć: & & \\
\hline Female/Kobieta & 334 & 75.7 \\
\hline Male/Mężczyzna & 107 & 24.3 \\
\hline Age [years]/Wiek [lata]: & & \\
\hline I5-34 & 197 & 44.7 \\
\hline $35-54$ & 140 & 31.7 \\
\hline$\geq 55$ & 104 & 23.6 \\
\hline Place of residence/Miejsce zamieszkania: & & \\
\hline City/Miasto & 334 & 75.7 \\
\hline Village/Wieś & 107 & 24.3 \\
\hline Occupation/Status zawodowy: & & \\
\hline Pupil/student/Uczeń/student & 64 & 14.5 \\
\hline Not working/Niepracujący & 33 & 7.5 \\
\hline Working/Pracujący & 221 & 50.1 \\
\hline Retired/pensioner/Emeryt/rencista & 113 & 25.6 \\
\hline Not avaiable/Brak danych & 10 & 2.3 \\
\hline
\end{tabular}

$(55,1 \%)$ (podgrupa I). U pozostałych $44,9 \%$ nie stwierdzono objawów choroby (podgrupa II).

Większość pacjentów była hospitalizowana w Klinice w marcu $(11,1 \%)$, lutym $(10,4 \%)$, czerwcu $(10,2 \%)$ oraz październiku i listopadzie $(9,3 \%)$ (ryc. 1). Specjalistą najczęściej kierującym pacjentów do Kliniki był dermatolog (95\%). Najrzadziej pacjenci byli kierowani przez alergologów (3\%) i lekarzy rodzinnych (2\%). W większości przypadków przyjęcie pacjentów następowało $\mathrm{w}$ trybie planowym.

\section{OMÓWIENIE}

Według najnowszych badań epidemiologicznych przeprowadzonych w różnych krajach CU występuje głównie u kobiet. Zależność tę potwierdzają analizy z wielu krajów, a także kilka badań polskich [3-19]. Autorzy niemieccy [19] określają chorobowość życiową pokrzywki na 8,8\% populacji ogólnej, a chorobowość życiową CU na 1,8\%. W analizie przeprowadzonej w Arabii Saudyjskiej większość pacjentów była w średnim wieku (ok. 35-50 lat). Badacze chińscy wykazali natomiast, że CU najczęściej dotyczy osób w wieku 20-39 lat [18].

Table 3. Occupation in age groups

Tabela 3. Status zawodowy w grupach wiekowych

\begin{tabular}{|c|c|c|c|c|c|}
\hline \multirow[t]{2}{*}{ Occupation/Status zawodowy } & & \multicolumn{3}{|c|}{ Age groups [years]/Grupy wiekowe [lata] } & \multirow[t]{2}{*}{ Total/tącznie } \\
\hline & & $15-34$ & $35-54$ & $\geq 55$ & \\
\hline \multirow[t]{2}{*}{ Pupil/student/Uczeń/student } & $N$ & 64 & 0 & 0 & 64 \\
\hline & $\%$ & 33.3 & 0.0 & 0.0 & 14.8 \\
\hline \multirow[t]{2}{*}{ Not working/Niepracujący } & $N$ & 21 & 12 & 0 & 33 \\
\hline & $\%$ & 10.9 & 8.6 & 0.0 & 7.7 \\
\hline \multirow[t]{2}{*}{ Working/Pracujący } & $N$ & 101 & 105 & 15 & 221 \\
\hline & $\%$ & 52.6 & 75.5 & 15.0 & 51.3 \\
\hline \multirow[t]{2}{*}{ Retired/pensioner/Emeryt/rencista } & $N$ & 6 & 22 & 85 & 113 \\
\hline & $\%$ & 3.1 & 15.8 & 85.0 & 26.2 \\
\hline \multirow[t]{2}{*}{ Total/Łącznie } & $N$ & 192 & 139 & 100 & 431 \\
\hline & $\%$ & 100.0 & 100.0 & 100.0 & 100.0 \\
\hline
\end{tabular}

\section{DISCUSSION}

According to the latest epidemiological studies carried out in various countries, CU mainly affects women. Analysis from many countries and a few Pol-
Silvares i wsp. [15] oszacowali średni wiek wystąpienia pierwszego epizodu pokrzywki na 30-40 lat, natomiast w badaniu Gaiga i wsp. [9] stwierdzili nieznaczną większość w przedziale wiekowym > 65 lat. Niektóre dostępne badania wskazują, że u pacjentów przeważa 
ish ones confirm this relationship [3-19]. The German authors [19] define the life prevalence of urticaria at $8.8 \%$ of the entire population and the life prevalence of CU at $1.8 \%$. The analysis carried out in Saudi Arabia showed that the respondents were mostly middle-aged ( $255-50$ years old). However, Chinese researchers indicated that most often $\mathrm{CU}$ affects patients aged 20-39 years [18]. Silvares et al. [15] estimated the average age of onset of the first episode of urticaria at 30-40 years, while Gaig et al. [9] indicate a slight majority in the age group $>65$ years. Some available studies indicate that patients mostly had higher education, while the place of their residence was usually the large city (over 500000 inhabitants) $[16,18]$. However, some researchers do not notice any significant correlation in this field $[8,9]$.

In our study, both in the $\mathrm{R}$ and in the $\mathrm{P}$ part, women prevailed. These data are confirmed by most European and world reports. The age of $\mathrm{R}$ patients was usually 15-34, which does not correspond to the available studies results. However, it is worth noting that CU may occur in various age groups. In this analysis, the mean age of onset of the first episode was very similar in both stages and the age of onset was higher for women than for men. These results are consistent with the statement that urticaria is predominant between the ages of 30 and 40 , and confirm data from Brazilian [15] and Chinese [18] analyses. The vast majority of patients in both parts of the study lived in the city $(75.7 \%$ and $64.1 \%)$, which, however, may be due to the location of the hospital in a large city (over 500000 inhabitants).

Differences in admissions between different months may result from the intensification of the disease process related to various diets, seasonality or the distribution of admissions related to the holiday periods. The number of patients admitted to the Clinic in particular years (2004-2006, 2007-2009 and 2010-2014), determined on the basis of the new guidelines, did not differ significantly and were very similar. The nature of the disease and, above all, its chronicity influenced the admission, which was mostly planned (97.7\%). Over the years, Spanish authors have noticed an increase in the percentage of patients with urticaria/angioedema (from $49 \%$ to $54.4 \%$ ) admitted to the Emergency Department, but only less than $3 \%$ of them required hospitalization for more than 3 days [8].

The predominance in referring by the dermatologist may arise from the presence of the Outpatient Clinic in the Dermatology Department and the fact that until 2015 a visit to a dermatologist did not require a referral, but also indicates the sporadic referrals from a general practitioner. Similar results were obtained by Spanish researchers - almost half of the patients (48.2\%) were referred to a dermatologist, and

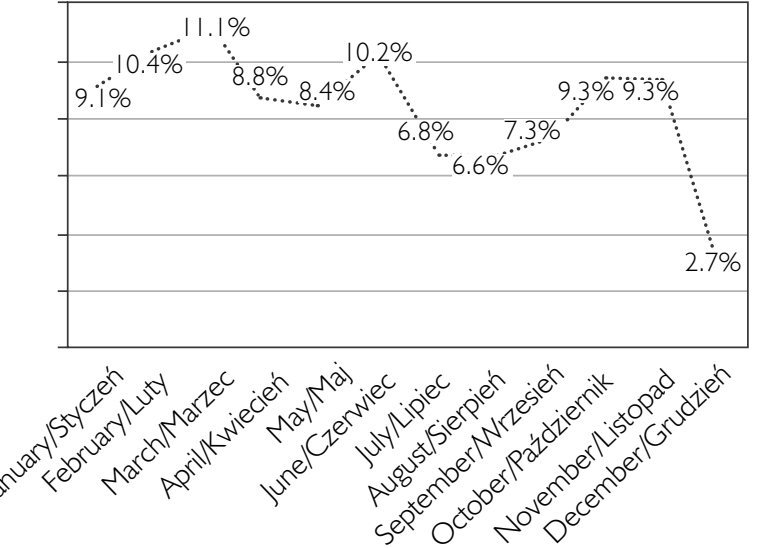

Figure I. Month of admission to the Department

Rycina I. Miesiąc przyjęcia do Kliniki

wykształcenie wyższe, a większość chorych mieszka w dużych miastach (powyżej 500000 mieszkańców)

[16, 18]. Część badaczy nie zauważa jednak istotnej zależności w tym zakresie $[8,9]$.

W przeprowadzonym przez nas badaniu większość pacjentów stanowiły kobiety - zarówno w części R, jak i części P analizy. Dane te są zgodne z większością doniesień europejskich i światowych. Wiek większości chorych w części R badania wynosił 15-34 lata. Wynik ten nie pokrywa się z obserwacjami z innych badań, jednak warto podkreślić, że CU może występować w różnych grupach wiekowych. W niniejszej analizie średni wiek wystąpienia pierwszego epizodu choroby był zbliżony w obu fazach badania i wyższy $\mathrm{u}$ kobiet niż u mężczyzn. Wyniki te są zgodne z poglądem, że pokrzywka występuje zazwyczaj w przedziale wiekowym 30-40 lat, oraz pokrywają się z danymi uzyskanymi w badaniu brazylijskim [15] i chińskim [18]. Większość chorych zakwalifikowanych do obu części badania mieszkała w miastach (odpowiednio $75,7 \%$ i $64,1 \%$ ). Może to jednak wynikać z lokalizacji szpitala w dużym mieście (liczącym powyżej 500000 mieszkańców).

Różnice w liczbie hospitalizacji pacjentów w poszczególnych miesiącach mogą wynikać z nasilenia procesu chorobowego związanego ze zróżnicowaniem diety, sezonowością lub rozłożeniem przyjęć do szpitala w związku z okresami wakacyjnymi i świątecznymi. Liczba chorych przyjętych do Kliniki w poszczególnych okresach (2004-2006, 2007-2009 i 2010-2014) wyznaczona na podstawie nowych wytycznych nie różniła się istotnie i była bardzo zbliżona. Ze względu na typ schorzenia, a przede wszystkim przewlekłość zmian chorobowych, większość pacjentów $(97,7 \%)$ była przyjmowana na oddział w trybie planowym. Hiszpańscy autorzy zauważyli na przestrzeni lat wzrost odsetka chorych z pokrzywką lub obrzękiem naczynioruchowym przyjmowanych na oddział ratunkowy (z 49\% 
$23.8 \%$ (much more frequently than shown in our own study) to an allergist. Moreover, patients with symptoms lasting less than 3 months tended to visit a general practitioner and a dermatologist, while those with longer episodes - an allergist [9]. On the contrary, Ferrer [8] indicated that the specialist referring to an allergist was primarily a general practitioner $(55.4 \%)$, while $28.1 \%$ were dermatologists, pediatricians and emergency medicine doctors. JankowskaKonsur et al. [20] pointed out to the predominance in visiting the general practitioner $(52.9 \%)$ by patients with the first episode and referrals to dermatologists and allergists.

The prospective part also assessed the percentage of people still suffering from chronic urticaria. More than half of the respondents $(55.1 \%)$ did not observe any symptom of CU. However, Brazilian reports [15] indicate that in the analyzed group of patients, improvement was recorded in $31.7 \%$.

\section{CONCLUSIONS}

The results obtained in this analysis were in varying agreement with the available world reports on various aspects of CU. According to current knowledge about $\mathrm{CU}$, this disease mainly affected women. The specificity of admissions may suggest a correlation with the severity of symptoms due to an uneven diet, as well as a lower number of admissions during the holiday season. Many interesting aspects of CU deserve further multicenter analysis.

\section{CONFLICT OF INTEREST}

The authors declare no conflict of interest. na 54,4\%). Mniej niż 3\% z nich wymagało hospitalizacji przez czas powyżej 3 dni [8].

Większość pacjentów była kierowana do dalszego leczenia przez dermatologa. Może to wynikać z obecności poradni dermatologicznej w Klinice Dermatologii oraz faktu, że do 2015 roku wizyta u specjalisty dermatologa nie wymagała skierowania. Wskazuje na to również sporadyczność skierowań wydawanych przez lekarza rodzinnego. Podobne wyniki otrzymali badacze hiszpańscy. Prawie połowa chorych $(48,2 \%)$ była kierowana do dermatologa, a 23,8\% (tj. znacznie więcej niż w naszym badaniu) do alergologa. Ustalono ponadto, że chorzy z objawami utrzymującymi się krócej niż 3 miesiące zazwyczaj udawali się do lekarza rodzinnego oraz dermatologa, natomiast pacjenci, u których występowały dłuższe epizody choroby, zazwyczaj alergologa [9]. W badaniu Ferrer [8] wskazano, że specjalistami kierującymi pacjentów do alergologa byli przede wszystkim lekarze rodzinni (55,4\%), natomiast 28,1\% stanowili dermatolodzy, pediatrzy oraz lekarze medycyny ratunkowej. W badaniu Jankowskiej-Konsur i wsp. [20] odnotowano, że pacjenci z pierwszym epizodem choroby zgłaszali się głównie do lekarza rodzinnego $(52,9 \%)$ oraz byli kierowani do dermatologów i alergologów.

W części prospektywnej niniejszego badania analizowano również odsetek pacjentów nadal chorujących na CU. Ponad połowa badanych (55,1\%) zadeklarowała brak objawów choroby. W doniesieniach brazylijskich [15] poprawa stanu $\mathrm{w}$ analizowanej grupie nastąpiła u $31,7 \%$ chorych.

\section{WNIOSKI}

Wyniki uzyskane w ramach przeprowadzonej analizy pokrywają się z większością dostępnych w światowym piśmiennictwie doniesień dotyczących różnych aspektów CU. Zgodnie z aktualnym stanem wiedzy choroba dotyczy głównie kobiet. Specyfika przyjęć może wskazywać na zależność między hospitalizacją i nasileniem objawów wskutek zróżnicowania diety. Zauważalna jest także mniejsza liczba przyjęć w okresach wakacyjnych i świątecznych. Wiele interesujących zagadnień dotyczących CU wymaga dalszych wieloośrodkowych badań.

\section{KONFLIKT INTERESÓW}

Autorzy nie zgłaszają konfliktu interesów.

\section{References}

Piśmiennictwo

1. Kruszewski J., Nowicki R., Śpiewak R. (red.).: Pokrzywki: rozpoznanie i leczenie. Medycyna Praktyczna, Warszawa 2011.

2. Zuberbier T., Aberer W., Asero R., Abdul Latiff A.H., Baker D., Ballmer-Weber B., et al.: The EAACI/GA²LEN/EDF/WAO Guideline for the definition, classification, diagnosis and management of urticaria: the 2017 revision and update. Allergy 2018, 73, 1393-1414. 
3. Rosman Y., Hershko A.Y., Meir-Shafrir K., Kedem R., Lachover-Roth I., Mekori Y.A., et al.: Characterization of chronic urticaria and associated conditions in a large population of adolescents. J Am Acad Dermatol 2019, 81, 129-135.

4. Antia C., Baquerizo K., Korman A., Bernstein J.A., Alikhan A.: Urticaria: a comprehensive review. Epidemiology, diagnosis, and work-up. J Am Acad Dermatol 2018, 79, 599-614.

5. Bakke P., Gulsvik A., Eide G.E.:. Hay fever, eczema and urticaria in southest Norway. Lifetime prevalences and association with sex, age, smoking habits, occupational airborne exposures and respiratory symptoms. Allergy 1990, 45, 515-522.

6. Dias G.A.C., Pires G.V., Rodrigues de Valle S.O., Dortas Junior S.D., Levy S., Tavares Franca A., et al.: Cross-cultural adaptation of the Brazilian-Portuguese version of the chronic urticaria quality-of-life questionnaire - CU-Q2oL. Allergy 2011, 66, 1487-1493.

7. Fatani M.I., Bahashwan E., Alfif K.A., Khan A.S., Chikh M.M., Kalo B.B.: The prevalence of urticaria and its clinical patterns in Makkah, Saudi Arabia. J Health Sci 2015, 5, 6-9.

8. Ferrer M.: Epidemiology, healthcare, resources, use and clinical features of different types of urticaria. Alergologica 2005. J Investig Allergol Clin Immunol 2009, 19, 21-26.

9. Gaig P., Olona M., Lejarazu D.M., Caballero M.T., Dominguez F.J., Echechipia S., et al.: Epidemiology of urticaria in Spain. J Investig Allergol Clin Immunol 2004, 14, 214-220.

10. Heng J.K., Koh L.J., Toh M.P.H.S., Aw D.C.W.: A study of treatment adherence and quality of life among adults with chronic urticaria in Singapore. Asia Pac Allergy 2015, 5, 197-202.

11. Lapi F., Cassano N., Pegoraro V., Cataldo N., Heiman F., Cricelli I., et al.: Epidemiology of chronic spontaneous urticaria: results from a nationwide, population-based study in Italy. Br J Dermatol 2016, 174, 996-1004.

12. Maurer M.: Urticaria and angioedema. Chem Immunol Allergy 2014, 100, 101-104.

13. Rudzki E., Rebandel P.: Częstość różnych odmian pokrzywki w zależności od płci. Dermatol Rev 1991, 78, $289-291$.

14. Rudzki E., Rebandel P., Prystupa K.: Porównanie częstości występowania poszczególnych odmian pokrzywki u dzieci i dorosłych. Przegl Derm 1991, 78, 141-143.

15. Silvares M.R.C., Rabello Coelho K.I., Dalben I., Lastoria J.C., Abbade L.P.F.: Sociodemographic and clinical characteristics, casual factors and evolution of a group of patients with chronic urticaria-angioedema. Sao Paulo Med J 2007, 125, 281-285.

16. Valero A., Herdman M., Bartra J., Ferrer M., Jauregui I., del Cuvillo A., et al.: Adaptation and validation of the Spanish version of the Chronic Urticaria Quality of Life Questionnaire (CU-Q2oL). J Investig Allerol Clin Immunol 2008, 18, 426-432.

17. Wrzyszcz M., Mazur K.: Epidemiologia chorób alergicznych: alergiczne choroby skóry, alergia na leki, alergia pokarmowa, alergia na jad owadów żądlących. Alerg Astma Immunol 1997, 2, 129-135.

18. Zhong H., Song Z., Chen W., Li H., He L., Gao T., et al.: Chronic urticaria in Chinese population: a hospital-based multicenter epidemiological study. Allergy 2014, 69, 359-364.

19. Zuberbier T., Balke M., Worm M., Edenharter G., Maurer M.: Epidemiology of urticaria: a representative cross-sectional population survey. Clin Exp Dermatol 2010, 35, 869-873.

20. Jankowska-Konsur A., Reich A., Szepietowski J., Polish Chronic Urticaria Working Group: Clinical characteristics and epidemiology of chronic urticaria: a nationwide, multicentre study on 1091 patients. Adv Dermatol Allergol 2019, 36, 184-191.

Received: 23.09 .2021

Accepted: 25.10 .2021

Otrzymano: $23.09 .2021 \mathrm{r}$.

Zaakceptowano: 25.10 .2021 r.

How to cite this article

Błaszczyk A., Jenerowicz D., Raciborski F., Sadowska-Przytocka A., Adamski Z., Czarnecka-Operacz M.: Socio-demographic aspects of chronic urticaria and the structure of hospitalization in patients of the Department of Dermatology, Poznan University of Medical Sciences. Dermatol Rev/Przegl Dermatol 2021, 108, 354-360. DOI: https:/ / doi.org/10.5114/dr.2021.113153 